\title{
Field performance of tissue culture derived cocoyam [Xanthosoma sagittifolium (L.) Schott] ${ }^{1}$
}

\author{
S. Zok', X. Ndzana and L. Nyochembeng ${ }^{2}$
}

J. Agric. Univ. P.R. 81(3-4):133-139 (1997)

\begin{abstract}
To respond to questions raised about field adaptability of tissue culture derived (TC) cocoyam, a study was conducted to compare TC cocoyam with cocoyam from non-tissue culture (NTC), i.e., vegetatively propagated. Throughout the vegetative cycle, TC plants out performed NTC plants in terms of plant vigor and average leaf number. In general, TC plants acclimatized in the greenhouse produced significantly more suckers than NTC plants, regardless of the period within the growing season. In the trial, the average number of cormels per plant varied from 6.66 to 12.44 . TC plants acclimatized for two months $\left(h_{1}\right)$, yielded higher than the other TC and TCN plants. The total weight (weight of cormels and corms) of TC plants of $h_{1}$ was significantly higher than in all other treatments. This finding suggests the importance of the acclimatization process in preparing TC derived plantlets for field conditions.
\end{abstract}

Key words: Xanthosoma sagittifolium (L.) Schott, cocoyam, tissue culture

\section{RESUMEN}

Comportamiento de yautia [Xanthosoma sagittifolium (L.) Schott] derivada de cultivo de tejido

Para responder a preguntas sobre la adaptabilidad al campo de la yautia derivada de cultivo de tejido (CT), se comparó ésta con la yautía no derivada de cultivo de tejido (NCT). Durante el ciclo vegetativo, las plantas CT superaron a las plantas NCT en términos de vigor de la planta y del número promedio de hojas. Por lo general, las plantas CT aclimatadas en el invernadero produjeron significativamente más hijuelos que las plantas NCT, sin importar la etapa de crecimiento de la planta. El número promedio de cormelos por planta varió de 6.66 a 12.44. Las plantas CT aclimatadas por dos meses (h) produjeron más cormelos que las otras plantas CT y que las plantas NCT. El peso total (peso de los cormelos y los cormos) de las plantas CT en $h_{1}$ fue significativamente mayor que el peso total obtenido en los otros tratamientos. Este hallazgo sugiere la importancia del proceso de aclimatización en la preparación de las plantas derivadas de cultivo de tejido para las condiciones del campo.

'Submitted to Editorial Board 4 November' 1993.

Jay P. Johnson Biotechnology Laboratory, Institute of Agronomic Rusarch, PMB 25 Buea, Cameroon. 


\section{INTRODUCTION}

Cocoyam, Xanthosoma sagittifolium (L.) Schott, is an important staple food crop in Cameroon. The starchy cormels are consumed in various ways and are an excellent source of carbohydrates and minerals, thus contributing to the basic diet requirements of the population.

Because of disease losses, and low multiplication rate of the traditional method of propagation, tissue culture techniques were considered as a practical means of eliminating pathogens and accelerating mass production of the planting stock of this important crop (Gupta, 1985; Hartman, 1974; Nguyen and Nguyen, 1987; Zok et al., 1990).

However, the available literature contains little information on field performances of tissue culture derived cocoyam. Many questions have been raised mainly concerning the adaptability of such material to field conditions, its growth characteristics as well as yield potentials. In order to answer some of these questions, we established field trials where tissue culture derived (TC) cocoyam was compared with non-tissue culture (NTC) cocoyam.

\section{MATERLALS AND METHODS}

Cocoyam suckers of the local white cultivar were obtained from Mamu and Soppo in South Western Cameroon. The shoot apices (0.5 to $0.6 \mathrm{~cm}$ ) were inoculated in a liquid medium composed of B5 major and minor minerals (Bamborg et al., 1968) devoid of any growth regulator (C6 medium). All cultures were kept in the controlled environment. chamber at 26 to $28^{\circ} \mathrm{C} ; 15,000$ lux and a photoperiod of 16 hours light.

Regeneration of plantlets was achieved eight to ten weeks after inoculation. The plantlets were then transferred for acclimatization into polyethylene bags filled with sterilized top soil and regularly watered with tap water in the greenhouse. From the plantlets under acclimatization, 360 were selected on the basis of size and time under acclimatization. They were divided into three groups: $\mathrm{h}_{1}, 24-\mathrm{cm}$ height, 2 mo under acclimatization; $h_{2}, 16 \mathrm{~cm}, 1.5 \mathrm{mo}$ under acclimatization; and $h_{3}, 10 \mathrm{~cm}, 1$ mo under acclimatization. Plant height was measured as the distance from ground level to the attachment point of the petiole of the tallest leaf. NTC cocoyam plants of similar sizes $\left(h_{1}, h_{2}, h_{3}\right)$ were used for the comparison. NTC plants, however, were not subjected to acclimatization.

The trial was planted August 1990 in a randomized complete block design with four replications at a planting density of $1 \mathrm{~m} \times 1 \mathrm{~m}$, with a total of $360 \mathrm{TC}$ plants and 360 NTC plants. 
The cocoyams were transplanted on flat plowed ground and mounded one month later. About one month after transplanting 48 plants, $12 \%$ of TC and $14 \%$ of NTC died out. This mortality was attributed mostly to the root rot disease (Pythium myriotylum), heavy rainfall and collar rot (Corticium sp.). The dead plants were replaced almost immediately. Plots were weeded regularly.

Four months after transplanting, we started data collection and observations on growth characteristics: number of leaves; multiple suckering; disease susceptibility, mainly root rot disease; and plant vigor. Yield data (number and weight of marketable cormels; total weight, i.e., weight of marketable cormels plus weight of corms) were also recorded at harvest nine months after transplanting (May 1991), and the two types of planting materials were compared. Only cormels weighing $20 \mathrm{~g}$ or more were considered as marketable. Disease score and plant vigor were evaluated as follows:

Disease score: The score of the disease in the field consisted in taking for each plant the number of yellowing leaves over the total number of leaves (Nzietcjieng, 1985).

Plant vigor score: 0 = dead; 1 = very poor; 2 = poor; 3 = fairly good; $4=$ good; 5 = excellent.

\section{RESULTS AND DISCUSSION}

Vegetative Growth Characteristics

Five months after planting (MAP) in the field, significant differences were found among the treatments with regard to plant vigor (Table 1). Two distinct groups of plants were observed. The first group

TABLE 1.-Vigor scoring for tissue culture derived and vegelatively propagated cocoyam plants at various stages of field growth.

\begin{tabular}{|c|c|c|c|}
\hline \multirow[b]{2}{*}{ Treatment } & \multicolumn{3}{|c|}{ Mean Vigor } \\
\hline & $5 \mathrm{MAP}$ & $6 \mathrm{MAP}$ & 7 MAP \\
\hline $\mathrm{TC} \mathrm{h}_{1}$ & 3.50 & 2.50 & 3.50 \\
\hline $\mathrm{TC} \mathrm{h}$ & 3.50 & 2.50 & 3.00 \\
\hline $\mathrm{TC} \mathrm{h}_{3}$ & 2.00 & 1.50 & 1.50 \\
\hline NTC $h_{1}$ & 1.50 & 1.00 & 1.50 \\
\hline $\mathrm{NTC} \mathrm{h}_{3}$ & 2.00 & 1.50 & 1.74 \\
\hline $\mathrm{NTC} \mathrm{h}_{3}$ & 1.25 & 1.00 & 1.50 \\
\hline LSD & 1.41 & 0.86 & 1.12 \\
\hline $\mathrm{CV}(\%)$ & 41.08 & 34.6 & 34.99 \\
\hline
\end{tabular}


TABLE 2.-Number of leaves per plant in tissue culture derived and vegetatively propagated cocoyam plants at different stages of field growth.

\begin{tabular}{lrrr} 
& \multicolumn{3}{c}{ Average number of leaves per plant } \\
Treatment & 5 MAP & 6 MAP & 7 MAP \\
\hline${ }^{T C ~} h_{1}$ & 4.15 & 4.10 & 4.15 \\
$\mathrm{TC} \mathrm{h}_{2}$ & 3.45 & 3.65 & 3.95 \\
$\mathrm{TC} h_{3}$ & 2.50 & 2.55 & 2.80 \\
$\mathrm{NTC}_{1}$ & 2.30 & 2.35 & 2.70 \\
$\mathrm{NTC} \mathrm{h}_{2}$ & 3.40 & 3.40 & 4.10 \\
$\mathrm{NTC} \mathrm{h}_{3}$ & 2.60 & 2.70 & 3.20 \\
$\mathrm{LSD}$ & 2.01 & 1.84 & 2.13 \\
$\mathrm{CV}(\%)$ & 43.48 & 39.24 & 40.62
\end{tabular}

had an average vigor score of 3.50 and included TC plants of $h_{1}(2$ mo under acclimatization) and $h_{2}$ ( 1.5 mo under acclimatization). The second group had a vigor score ranging from 1.25 to 2.00 and included the remaining treatments (the smallest TC plants and the NTC cocoyams). Although some slight differences in plant vigor were observed at 6 MAP and 7 MAP, the ranking of treatments remained the same as for 5 MAP. Throughout the cycle, TC plants performed better than NTC ones.

For average leaf number (Table 2), there was no significant difference among treatments. At $5 \mathrm{MAP}$, leaf number ranged from 2.50 to 4.15 leaves per plant in TC plants, and from 2.30 to 3.40 in NTC plants. The same pattern was maintained at 6 MAP and 7 MAP.

The stagnant results throughout the cycle for vigor and leaf number as observed $5 \mathrm{MAP}, 6 \mathrm{MAP}$ or $7 \mathrm{MAP}$ may be explained by the fact that in Xanthosoma sagittifolium most growth characteristics reach a maximum during the 4 th to 5 th MAP (Wilson, 1984). No abnormal growth was observed among TC cocoyams, unlike in some other species where high rates of somaclonal variation have been reported (Vuylsteke, 1989).

Disease scores at 5 MAP were analyzed (Table 3). The most susceptible plants were the $\mathrm{TC} h_{3}$ with a disease score of 0.61 , and the least susceptible plants were those of NTC $h_{1}(0.26)$. These two treatments were found to be statistically different. There were no significant differences among the remaining treatments, which had disease scores ranging from $0.39\left(\mathrm{NTC}_{3}\right)$ to $0.48\left(\mathrm{NTC} \mathrm{h}_{2}\right)$

Concerning sucker production in general, TC plants of $h_{1}$ and $h_{2}$ produced significantly more suckers than NTC plants regardless of the time after planting (Table 4). The suckers generally grew from cormels 
TABLE 3.-Number of diseased leaves per total number of leaves in tissue culture derived and vegetatively propagated cocoyam plants five months after planting.

\begin{tabular}{lc} 
Treatment & $\begin{array}{c}\text { Disease } \\
\text { (mean per plant) }\end{array}$ \\
\hline $\mathrm{TC} h_{1}$ & 0.39 \\
$\mathrm{TC} h_{2}$ & 0.47 \\
$\mathrm{TC} h_{3}$ & 0.61 \\
$\mathrm{NTC} h_{1}$ & 0.26 \\
$\mathrm{NTC} h_{2}$ & 0.48 \\
$\mathrm{NTC} h_{3}$ & 0.39 \\
LSD & 0.27 \\
$\mathrm{CV}(\%)$ & 0.47 \\
\hline
\end{tabular}

that had sprouted. It is noteworthy that the sucker production which started $4 \mathrm{MAP}$ declined at $5 \mathrm{MAP}$ and $6 \mathrm{MAP}$ and increased again 7 MAP. This was true for all the treatments. The decline in sucker production corresponds to the dry season. The lowest point in all the curves was the peak of the dry season. The sucker production was stimulated $7 \mathrm{MAP}$, a time which corresponded to the beginning of the rainy season.

The results obtained in this experiment confirmed earlier observations on the propensity of TC cocoyam to produce suckers [Roots and Tubers Research Project (ROTREP), 1989].

\section{Yield Parameters}

The number of marketable cormels per plant harvested varied from 6.32 to 12.44 (Table 5). TC plants of $h_{1}$ yielded highest. The only significant difference was between $\mathrm{TC} h_{1}$ and $\mathrm{TC} h_{2}$.

TABLE 4-Number of suckers per plant in tissue culture derived and vegetatively propagated cocoyam plants at different stages of growth.

\begin{tabular}{lcccc} 
& \multicolumn{4}{c}{ Number of suckers per plant } \\
Treatment & $4 \mathrm{MAP}$ & $5 \mathrm{MAP}$ & $6 \mathrm{MAP}$ & $7 \mathrm{MAP}$ \\
\hline $\mathrm{TCh} \mathrm{h}_{1}$ & 4.75 & 3.52 & 2.35 & 5.82 \\
$\mathrm{TC} \mathrm{h}_{2}$ & 6.37 & 3.67 & 1.85 & 5.55 \\
$\mathrm{TC} \mathrm{h}$ & 1.52 & 1.32 & 1.37 & 2.35 \\
$\mathrm{NTC} \mathrm{h}_{1}$ & 0.65 & 0.20 & 0.17 & 0.55 \\
$\mathrm{NTC} \mathrm{h}_{2}$ & 0.32 & 0.30 & 0.40 & 1.30 \\
$\mathrm{NTC} \mathrm{h}_{3}$ & 0.50 & 0.25 & 0.25 & 0.47 \\
$\mathrm{LSD}$ & 2.15 & 2.65 & 1.22 & 2.83 \\
$\mathrm{CV}(\%)$ & 60.63 & 14.10 & 76.40 & 70.36 \\
\hline
\end{tabular}


TABLE 5.-Number of cormels per planl, average weight of marketable cormels, marketable cormel yield (t/ha), corm yield (t/ha) and total yield (t/ha) in tissue culture derived and vegetatively propagated cocoyam. plants nine months after planting.

\begin{tabular}{lccccc}
\hline Treatment & $\begin{array}{c}\text { Number of } \\
\text { comels per } \\
\text { plant }\end{array}$ & $\begin{array}{c}\text { Av. wt. of } \\
\text { marketable } \\
\text { cormel (g) }\end{array}$ & $\begin{array}{c}\text { Marketable } \\
\text { cormel yield } \\
\text { (t/ha) }\end{array}$ & $\begin{array}{c}\text { Corm yield } \\
\text { (t/ha) }\end{array}$ & $\begin{array}{c}\text { Total yield } \\
\text { (t/ha) }\end{array}$ \\
\hline $\mathrm{TC} \mathrm{h}_{1}$ & 12.44 & 70.93 & 8.49 & 1.7 .74 & 31.24 \\
$\mathrm{TC} \mathrm{h}_{2}$ & 6.32 & 43.11 & 3.10 & 8.98 & 19.13 \\
$\mathrm{TC} \mathrm{h}_{3}$ & 8.78 & 49.98 & 6.45 & 7.10 & 17.43 \\
$\mathrm{NTC}_{2}$ & 7.40 & 51.74 & 3.72 & 3.75 & 10.99 \\
$\mathrm{NTC} \mathrm{h}_{2}$ & 8.66 & 69.89 & 6.02 & 6.46 & 18.02 \\
$\mathrm{NTC} \mathrm{h} h_{3}$ & 6.66 & 62.18 & 3.90 & 8.16 & 15.47 \\
LSD & 6.05 & 31.70 & 6.19 & 4.39 & 1.0 .16 \\
$\mathrm{CV}(\%)$ & 47.92 & 36.29 & 77.99 & 36.46 & 36.03 \\
\hline
\end{tabular}

No statistical difference was found among the different treatments concerning the average weight of marketable cormels and marketable cormel yield (Table 5). There is, however, a strong correlation $(r=0.89)$ between number of cormels per plant and weight of cormels. In general, the cormels were small in all treatments. This result was not surprising, given the luxuriant vegetative growth reported throughout the growth cycle, especially for the TC plants. This finding confirmed that vegetative growth is achieved at the expense of cormel production. It is likely that the abundant suckers competed for carbohydrates with the corms and cormels and that this competition reduced cormel yield. It will be necessary to investigate whether the removal of suckers during the growing season affects corm and cormel yield and to assess the behavior of suckers when used as planting materials, as well as the importance of soil moisture during the cormel bulking period.

Concerning total yield (weight of marketable cormels plus weight of corms), TC $h_{1}$ significantly outyielded the other treatments (Table 5). The yield obtained is in the range found in the same field for other cocoyam clones planted from NTC material (Wutoh et al., 1991).

On the basis of the above results, it can be concluded that TC plants performed better than NTC plants in terms of plant vigor, sucker production, yield of marketable cormels, corm yield and total yield. However, among TC plants, it would be advisable to use TC plants of $h_{1}$, (2 mo under aclimatization, $24 \mathrm{~cm}$ high) for transplanting into the field, since these plants seem to have reached an adequate size and the physiological stage to endure difficult field conditions. 


\section{LITERATURE CITED}

Gamborg, O. L., R. A. Miller and K. Ojima, 1968. Nutrient requirements of suspension cultures of soybean root cell. Exp. Cell. Res. 50:151-158.

Gupta, P. P., 1985. Plant regeneration and variabilities for tissue culture of cocoyams (Xanthosoma sagithifolium and $X$. vinlaceum). Planl Cell Reports 4:88-91.

Hartman, R. D., 1974. Dasheen Mosaic Virus and other phytopathogens eliminated from Caladium, Taro and Cocoyam by culture of shoot tips. Phytopathology 64:237-240.

Nguyen, T. Q. and V. U. Nguyen, 1987. Aroid propagation by tissue cultures of cocoyams (Xanthosoma violaceum.). Hortscience 22(4):671-672.

Nzietchueng, S., 1985. Genre Xanthosoma (Macabo) el contraintes de production: cas particulier de la pourriture racinaire causée par Pythium myriotylum au Cameroun. These Dr. es Sciences Univ. Yaounde $253 \mathrm{p}$.

ROTREP, 1989. Roots and Tubers Research Project. Annual Report, 1989.

Vuylsteke, D. R., 1989. Shoot-tip culture for the propagation, conservation and exchange of Musa germplasm. IBPGR, Rome.

Wilson, J. E. 1984. Cocoyam, In The Physiology of Tropical Field Crops, edited by Petex R. Goldworthy and N. M. Fisher; P. 589-605

Wutoh, J. G., J. T. Tambong, M. M. Mehoka and S. Nzietchueng, 1991. Field evaluation of cocoyam (Xanthosoma sagittifolium (L.) Schott cv "white" for tolerance to the root rot disease caused by Phytium myriotylum. In Proceedings of the 9th Symposium of ISTRC, ACCRA (Ghana), 20-26 Oct. 1991.

Zok, S., J. G. Wutoh, J. T. Tambong and L. M. Nyochembeng, 1990. Contribution of biotechnology to rapid seedstock multiplication of root and tuber foodcrops in Cameroon. Proceedings of the VIIth International Congress of IAPTC, Amsterdam, The Netherlands, 24-29 June, 1990. 